\title{
Potent in vivo anti-malarial activity and representative snapshot pharmacokinetic evaluation of artemisinin-quinoline hybrids
}

\author{
Marli C Lombard', David D N'Da ${ }^{1 *}$, Christophe Tran Van Ba², Sharon Wein'², Jennifer Norman ${ }^{3}$, \\ Lubbe Wiesner ${ }^{3+}$ and Henri Vial ${ }^{2+}$
}

\begin{abstract}
Background: Because Plasmodium falciparum displays increase tolerance against the recommended artemisinin combination therapies (ACT), new classes of anti-malarial drugs are urgently required. Previously synthesized artemisinin-aminoquinoline hybrids were evaluated to ascertain whether the potent low nanomolar in vitro anti-plasmodial activity would carny over in vivo against Plasmodium vinckei. A snapshot pharmacokinetic analysis was carried out on one of the hybrids to obtain an indication of the pharmacokinetic properties of this class of anti-malarial drugs.

Methods: In vitro activity of hybrids 2 and 3 were determined against the 3D7 strain of $P$. falciparum. Plasmodium vinckei-infected mice were treated with hybrids $1-3$ for four days at a dosage of $0.8 \mathrm{mg} / \mathrm{kg}, 2.5 \mathrm{mg} / \mathrm{kg}, 7.5 \mathrm{mg} / \mathrm{kg}$ or $15 \mathrm{mg} / \mathrm{kg}$ intraperitoneally (ip), or orally (per os) with $2.7 \mathrm{mg} / \mathrm{kg}, 8.3 \mathrm{mg} / \mathrm{kg}, 25 \mathrm{mg} / \mathrm{kg}$ or $50 \mathrm{mg} / \mathrm{kg}$. Artesunate was used as reference drug. A snapshot oral and IV pharmacokinetic study was performed on hybrid 2.
\end{abstract}

Results: Hybrids 1 - 3 displayed potent in vivo anti-malarial activity with $\mathrm{ED}_{50}$ of 1.1, 1.4 and $<0.8 \mathrm{mg} / \mathrm{kg}$ by the ip route and 12, 16 and $13 \mathrm{mg} / \mathrm{kg}$ per os, respectively. Long-term monitoring of parasitaemia showed a complete cure of mice (without recrudescence) at $15 \mathrm{mg} / \mathrm{kg}$ via ip route and at $50 \mathrm{mg} / \mathrm{kg}$ by oral route for hybrid 1 and 2 , whereas artesunate was only able to provide a complete cure at $30 \mathrm{mg} / \mathrm{kg}$ ip and $80 \mathrm{mg} / \mathrm{kg}$ per os.

Conclusions: These compounds provide a new class of desperately needed anti-malarial drug. Despite a short half-life and moderate oral bioavailability, this class of compounds was able to cure malaria in mice at very low dosages. The optimum linker length for anti-malarial activity was found to be a diaminoalkyl chain consisting of two carbon atoms either methylated or unmethylated.

Keywords: Malaria, Artemisinin, Quinoline, Hybrid, Pharmacokinetics, In vivo activity

\section{Background}

Partial artemisinin resistance has emerged in western Cambodia and has the potential to spread to different parts of the region, subsequently becoming a global threat for malaria control and treatment. There are currently no alternative drugs to artemisinin derivatives [1-3]. A major drawback of the artemisinin derivatives is their short half-lives and susceptibility to recrudescence, when given as monotherapy [4]. CYP-mediated autoinduction

\footnotetext{
* Correspondence: david.nda@nwu.ac.za

${ }^{\dagger}$ Equal contributors

${ }^{1}$ Pharmaceutical Chemistry, North-West University, Potchefstroom 2531, South Africa

Full list of author information is available at the end of the article
}

of artemisinin metabolism has been reported to be the underlying mechanism recrudescence $[5,6]$.

Hybrid molecules, as described by Meunier [7], are composed of two distinct moieties joined covalently, which will act as two distinct pharmacophores. The risk of treatment failure is reduced and the partner drug may be protected from the spread of resistance. The concept of the formation of a hybrid, especially in the treatment of malaria, has already been adopted by a number of groups [7-12].

Walsh et al. synthesized a novel artemisinin-quinine hybrid by coupling dihydroartemisinin directly to the carboxylic acid derivative of quinine via an ester-linkage [13]. The hybrid had potent in vitro activity against 
sensitive and resistance strains of Plasmodium falciparum that was superior to that of quinine alone, artemisinin alone and to a 1:1 mixture of the two, suggesting a tangible benefit in terms of activity from linking the two molecules covalently [14].

The hybrids of the present study have been previously synthesized [15]. DHA (dihydroartemisinin) was treated with bromoethanol in the presence of boron trifluoride etherate to give 2-(10ß-dihydroartemisinoxy) ethylbromide, which upon treatment with different aminoquinolines provided the new hybrids. All compounds were obtained as the 10- $\beta$-isomers [16] and displayed good selectivity towards $P$. falciparum in vitro $(\mathrm{SI} \geq 20)$. Based on $\mathrm{IC}_{50}$, resistance index (RI) and selectivity index (SI) values, those hybrids with the best anti-plasmodial activity were selected for further investigation. Hybrids $\mathbf{1}-\mathbf{3}$ (Figure 1) were prepared as the oxalates for stability and solubility reasons.

The aim of this study was to elucidate whether the potent in vitro anti-plasmodial activity of the selected three hybrids would be carried over in vivo against Plasmodium vinckei and to determine the pharmacokinetic properties of this class of anti-malarial drugs by performing a snapshot pharmacokinetic analysis on hybrid 2 .

\section{Methods}

\section{In vitro anti-malarial activity against 3D7 strain}

The 3D7 strain of P. falciparum was asexually cultured in human blood in complete medium (RPMI 1640 supplemented with $25 \mathrm{mM}$ Hepes, $\mathrm{pH} 7.4$ ) and $10 \% \mathrm{AB}+$ human serum [17]. Drug effects were measured in microtitre plates on suspensions of asynchronous $P$. falciparum infected red blood cells $(1.5 \%$ final haematocrit, $0.6 \%$ parasitaemia) according to Desjardins et al. [18]. Drugs, previously dissolved in DMSO, were diluted in culture medium so that the final DMSO concentration never exceeded $0.25 \%$. After $48 \mathrm{~h}$ incubation at $37^{\circ} \mathrm{C}$ parasite growth was assayed by the incorporation of $\left[{ }^{3} \mathrm{H}\right]$-hypoxanthine $(0.5 \mu \mathrm{Ci} /$ well, $22.2 \mathrm{kBq})$ in parasitic nucleic acids for
18 h. Analyses of dose-effect curves were performed with the Graphpad Prism analytical software. The results are expressed as $\mathrm{IC}_{50}$, corresponding to the drug concentration leading to $50 \%$ parasite growth inhibition. Values are the means of at least two independent experiments (different cell cultures, different drug dilution stocks), each performed in duplicates.

\section{In vivo anti-malarial activity against $P$. vinckei}

In each experiment, female Swiss OF1 mice (Charles River Laboratories, France) were infected on day 0 (D0) by intravenous injection into the caudal vein of $10^{7} P$. vinckei-infected erythrocytes (BY strain) in $200 \mu \mathrm{l} 0.9 \%$ $\mathrm{NaCl}$. These injections lead to a parasitaemia on day 1 (D1) of between $0.3 \%$ and $1.5 \%$. Mice were treated once a day for four days on D1, D2, D3 and D4 intraperitoneally (ip) with $0.8 \mathrm{mg} / \mathrm{kg}, 2.5 \mathrm{mg} / \mathrm{kg}, 7.5 \mathrm{mg} / \mathrm{kg}$ or $15 \mathrm{mg} / \mathrm{kg}$ of the compound, or orally (per os) with $2.7 \mathrm{mg} / \mathrm{kg}, 8.3 \mathrm{mg} / \mathrm{kg}, 25 \mathrm{mg} / \mathrm{kg}$ or $50 \mathrm{mg} / \mathrm{kg}$. Hybrids 1-3 were dissolved in DMSO and were administered in volumes of $100 \mu \mathrm{L}$. Each group consists of 3 mice and the control group received only the vehicle (DMSO). On $\mathrm{D} 5$, the $\mathrm{ED}_{50}$ (effective dose) was determined using Giemsa-stained thin blood smears and flow cytometry (Yoyo 1 iodide (491/509) - Invitrogen) [19]. The survival of the mice was monitored for up to one month after the end of the treatment.

\section{Snapshot pharmacokinetics}

The pharmacokinetic properties of hybrid $\mathbf{2}$ were evaluated in a mouse model. This study was approved by the Ethics Committee of the University of Cape Town, approval number 009/034.

\section{Mouse strain, formulation and mice study protocol}

The animals used were male C57/BL6 mice, weighing approximately $25 \mathrm{~g}$ each. The concentration of the test compound formulations was prepared at $20 \mathrm{mg} / \mathrm{kg}$ for

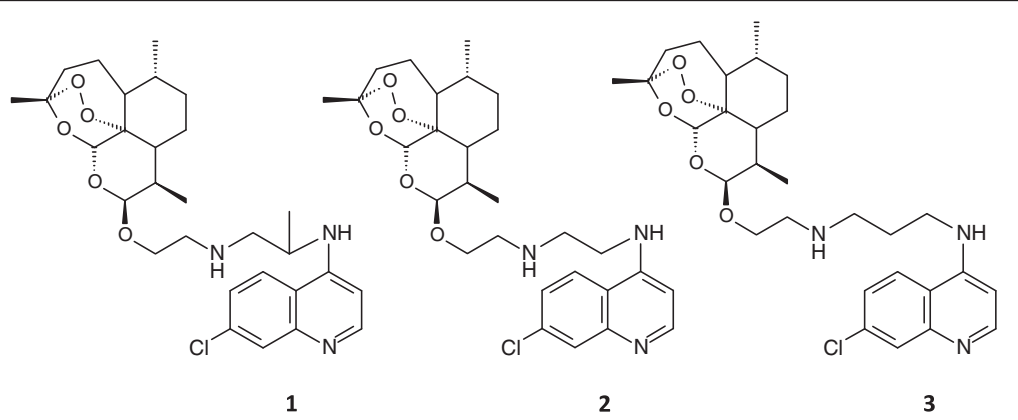

Figure 1 The structures of artemisinin-quinoline hybrids 1 - 3. The chemical structures of C-10 acetal artemisinin-aminoquinoline hybrids $\mathbf{1}$ - $\mathbf{3}$ only differs with one methylene group in the linker and its position in the chain. The linkers of hybrid $\mathbf{1}-\mathbf{3}$ respectively are: 2-[(2-aminoethyl) amino]ethyl, 2-[(2-aminopropyl)amino]ethyl and 2-[(3-aminopropyl)amino]ethyl. 
the oral dose and at $2 \mathrm{mg} / \mathrm{kg}$ for the intravenous (IV) experiments. Hybrid 2 was dissolved in DMSO, and water was added $(1: 9, \mathrm{v} / \mathrm{v})$. The test compounds were administered orally and intravenously. Test animals were randomly divided into 2 groups. Each group consisted of three mice. Group A received hybrid $\mathbf{2}$ at an oral gavage dose concentration of $20 \mathrm{mg} / \mathrm{kg}$. Group B received hybrid $2 \mathrm{IV}$ at a concentration of $2 \mathrm{mg} / \mathrm{kg}$. The animals were anesthetized for the IV via dorsal penile vein bolus injections. Blood samples $(40 \mu \mathrm{L})$ were collected before, and at 10, 20, 30, 40 and 50 min after oral gavage dosing (Group A), and at 5, 15, 25, 35 and 50 min after IV dosing (Group B). The blood samples were collected on ice into $0.8 \mathrm{~mL}$ lithium heparin gel tubes. The samples were centrifuged at $1500 \mathrm{G}$ for $10 \mathrm{~min}$, and the plasma layer was transferred to $1.5 \mathrm{~mL}$ micro centrifuge tubes and stored at $-80^{\circ} \mathrm{C}$ until analysis.

\section{Pharmacokinetic sample analysis}

An LC/MS/MS system (Shimadzu HPLC and an AB Sciex API 3200 Q-Trap mass spectrometer) was used to analyse the plasma samples. A sensitive and selective assay was developed to determine the plasma concentrations of hybrid 2.

\section{LC/MS/MS summary}

Twenty microliters of plasma was precipitated with a $100 \mu \mathrm{l}$ acetonitrile. The samples were vortexed for one minute, sonicated for $5 \mathrm{~min}$ and centrifuged at 13,000 G for $5 \mathrm{~min}$. The supernatant was transferred to a 96 well plate, and $10 \mu \mathrm{L}$ was injected onto the HPLC column.

Gradient chromatography was performed using a Phenomenex, Gemini-NX (5 $\mu \mathrm{L}, \mathrm{C} 18,110 \mathrm{~A}, 50 \times 2 \mathrm{~mm})$ analytical column using a Shimadzu HPLC. Mobile phase A consisted of acetonitrile and mobile phase B consisted of a mixture of $4 \mathrm{mM}$ ammonium acetate and $0.1 \%$ formic acid $(1: 1, \mathrm{v} / \mathrm{v})$. The organic solvent was increased from $5 \%$ to $95 \%$ over $4 \mathrm{~min}$, with an equilibration time of $3 \mathrm{~min}$ between 4 and $7 \mathrm{~min}$. The flow-rate was set at $0.5 \mathrm{~mL} / \mathrm{min}$ and $10 \mu \mathrm{L}$ was injected onto the analytical column. The samples were cooled to $5^{\circ} \mathrm{C}$ whilst awaiting injection.

Detection of hybrid 2 was performed using an $\mathrm{AB}$ Sciex API 3200 Q-Trap mass spectrometer (ESI in the positive ion mode, MRM). The mass spectrometer was operated at unit resolution in the multiple reaction monitoring (MRM) mode, monitoring the transition of the protonated molecular ions at $\mathrm{m} / z 532.3$ to the product ions at $\mathrm{m} / \mathrm{z}$ 205.2. Calibration standards (8 levels) were prepared in mouse plasma, at concentrations ranging from 7.8 to $1000 \mathrm{ng} / \mathrm{mL}$. The calibration standards were analysed in duplicate with the study samples.

\section{Pharmacokinetic parameters and statistical evaluation}

Non-compartmental analysis was used to calculate the pharmacokinetic parameters for hybrid 2 (Summit pharmacokinetic software, version 2.0). The following pharmacokinetic parameters were calculated: Maximum plasma concentration $(\mathrm{Cmax}[\mathrm{ng} / \mathrm{mL}])$ and corresponding time (Tmax $[\mathrm{min}])$, Apparent terminal half-life $\left(\mathrm{t}_{1 / 2}[\mathrm{~min}]\right)$, Total plasma exposure $\left(\mathrm{AUC}_{0-\mathrm{Inf}}[\mathrm{ng} \cdot \mathrm{min} / \mathrm{mL}]\right)$, Volume of distribution $[\mathrm{L} / \mathrm{kg}]$, Plasma clearance $(\mathrm{CL}[\mathrm{L} / \mathrm{min} / \mathrm{kg}])$ and percentage oral bioavailability (\%BA).

\section{Results}

In vitro anti-malarial activity

The in vitro anti-plasmodial activity was determined for hybrid 2 and 3 against the 3D7 strain of P. falciparum. The activity of all three compounds was previously determined against the D10 and Dd2 strain. All results are displayed in Table 1, including reference drugs; DHA and chloroquine (CQ). The activity against the 3D7 strain resulted in similar values, when compared to the anti-plasmodial activity previously determined for these hybrids. Hybrid 3 displayed a very potent anti-plasmodial activity against the $3 \mathrm{D} 7$ strain, with an $\mathrm{IC}_{50}$ value of $5.15 \pm$ $\mathrm{nM}$, whereas the activity of hybrid 2 was similar to that of CQ $(20.5 \pm$ and $20.0 \pm 1.6 \mathrm{nM}$, respectively). Although all three hybrids displayed very similar $\mathrm{IC}_{50}$ values against all three strains, hybrid $\mathbf{3}$ had the best activity against all three strains and was, therefore, classified as the best compound based on the in vitro anti-plasmodial activity.

\section{In vivo anti-malarial activity of hybrids 1-3 after four injections by the intraperitoneal route (ip)}

At $7.5 \mathrm{mg} / \mathrm{kg}$ ip hybrid 1 displayed a strong anti-malarial effect. Parasitaemia decreased from $0.67 \%$ to $0.27 \%$ between day 1 and 2. No parasitaemia was observed from day 3 up to day 11 . However, at this dose recrudescence was observed for at least one mouse. A very potent antimalarial effect was exerted by artemisinin-quinoline hybrid 1 at $15 \mathrm{mg} / \mathrm{kg}$, inducing a rapid and total clearance of the parasites. On day 2, just before the second injection, parasitaemia decreased from $1 \%$ to $0.1 \%$. All the

Table 1 In vitro $\mathrm{IC}_{50}$ of hybrids 1-3 against 3D7, D10 and Dd2 P. falciparum strains

\begin{tabular}{cccc}
\hline Compound & \multicolumn{3}{c}{ IC $_{\mathbf{5 0}}(\mathbf{n M}) \pm$ SD } \\
\cline { 2 - 4 } & 3D7 & D10 & Dd2 \\
\hline $\mathbf{1}$ & ND & $14.9 \pm 0.1$ & $20.8 \pm 3.6$ \\
$\mathbf{2}$ & $20.5 \pm 1.2$ & $21.5 \pm 0.1$ & $25.7 \pm 1.1$ \\
$\mathbf{3}$ & $5.2 \pm 0.7$ & $14.3 \pm 2.7$ & $19.8 \pm 0.3$ \\
DHA & $\mathrm{ND}$ & $5.1 \pm 0.6$ & $2.1 \pm 0.3$ \\
CQ & $20 \pm 1.6$ & $21.5 \pm 6.7$ & $157.9 \pm 52.7$ \\
\hline ND $=$ not determined. & & &
\end{tabular}


mice were alive on day 30 and no parasitaemia was observed from day 3 until after 30 days.

Hybrid 2 displayed a strong anti-malarial effect at $7.5 \mathrm{mg} / \mathrm{kg}(\mathrm{P}=0.03 \%$ vs. $86 \%$ for the control group). However, recrudescence was observed which led to mice death between day 14 and 17. At $15 \mathrm{mg} / \mathrm{kg}$ ip potent in vivo anti-malarial activity was observed for hybrid 2 . On day 5 , parasitaemia was $0 \%$ of the control ( $\mathrm{P}=0 \%$ vs. $86 \%$ for the control group). At this dose, long term monitoring showed no recrudescence, with no visualized parasitaemia on day 17 and $100 \%$ of survival beyond day 20 .

At 2.5 and $7.5 \mathrm{mg} / \mathrm{kg}$, hybrid 3 decreased parasitaemia to $0.02 \%$ of the control on day 5 for both two doses ( $\mathrm{P}=0.02 \%$ vs. $86 \%$ for the control group). Recrudescence occurred, which led to mice death between day 14 and 18 . A strong anti-malarial effect was observed in vivo against $P$. vinckei at $15 \mathrm{mg} / \mathrm{kg}$ with hybrid 3 resulting in parasitaemia of $0.01 \%$ of the control on day 5 . No recrudescence was observed for two of the three mice. However, the third mouse died on day 8 , indicating $66 \%$ of survival beyond day 20 .

\section{In vivo anti-malarial activity of hybrids 1-3 after four dosages by the oral route}

At 25 and $50 \mathrm{mg} / \mathrm{kg}$ per os, hybrid 1 displayed very rapid and potent in vivo anti-malarial activity against $P$. vinckei. Parasitaemia decreased from $0.6 \%$ (day 1 ) to $0.01 \%$ and $0 \%$ for 25 and $50 \mathrm{mg} / \mathrm{kg}$ (day 2), respectively, and was $0 \%$ on day 5 . However, recrudescence was observed at $25 \mathrm{mg} / \mathrm{kg}$ for two mice, leading to $66 \%$ of mortality on day 17 . No recrudescence was observed at $50 \mathrm{mg} / \mathrm{kg}$ per os for hybrid $\mathbf{1}$. All mice were alive on day 30.

A strong anti-malarial effect was observed with hybrid 2 at $25 \mathrm{mg} / \mathrm{kg}$ with parasitaemia of $8 \%$ of the control on day 5. Rapid recrudescence of parasitaemia was shown by mice death between day 8 and 15 . At $50 \mathrm{mg} / \mathrm{kg}$ hybrid 2 displayed a potent in vivo anti-malarial activity, with parasitaemia $0 \%$ of the control on day 5 ( $\mathrm{P}=0 \% v s$. 93\% for the control group). Long term monitoring showed no recrudescence, with no parasite visualized on day 17 thin blood smears and 100\% survival beyond day 20 , indicating a total clearance of parasitaemia.

Hybrid $\mathbf{3}$ exerted a strong anti-malarial effect at $25 \mathrm{mg} / \mathrm{kg}$ ( $\mathrm{P}=0.02 \%$ vs. $93 \%$ for the control group). Delayed recrudescence led to mice death on day 15 . Very potent in vivo anti-malarial activity was displayed at $50 \mathrm{mg} / \mathrm{kg}$. The treatment decreased parasitaemia on day 5 to $0.01 \%$ of the control ( $\mathrm{P}=0.01 \%$ vs. $93 \%$ for the control group). At this dose, 2 of the 3 mice showed no recrudescence, with no visualized parasitaemia on day 17. The third mouse showed $51 \%$ of parasitaemia on day 17 and died on day 18 . At $50 \mathrm{mg} / \mathrm{kg}$ survival beyond day 17 is $66 \%$.

\section{In vivo $\mathrm{ED}_{50}$ of artemisinin-quinoline hybrids}

After $P$. vinckei infected mice were treated with hybrids 1 - 3 ip and per os parasitaemia, determined on day 5, were expressed as a percentage of the control and displayed as the $\mathrm{ED}_{50}$ on the graphs for each compound, respectively. Oral absorption was calculated by the $\mathrm{ED}_{50} \mathrm{ip} / \mathrm{ED}_{50}$ per os ratio. The ip/per os ratio provides an estimation of oral bioavailability for each compound.

Hybrid 1 presented good $E_{50}$ values of $1.1 \mathrm{mg} / \mathrm{kg}$ ip and $12 \mathrm{mg} / \mathrm{kg}$ per os (Figure 2A), with an ip/per os ratio of $9 \%$ in DMSO. $\mathrm{ED}_{50}$ values for hybrid 2 were $1.4 \mathrm{mg} /$ $\mathrm{kg}$ for ip route and $16 \mathrm{mg} / \mathrm{kg}$ for per os route (Figure $2 \mathrm{~B}$ ). Oral absorption is evaluated by the $\mathrm{ED}_{50} \mathrm{ip} / \mathrm{ED}_{50}$ per os ratio which was $9.75 \%$ in DMSO. After a four day treatment with hybrid 3, the $\mathrm{ED}_{50}$ ip was less than $0.8 \mathrm{mg} / \mathrm{kg}$ and $13 \mathrm{mg} / \mathrm{kg}$ for the oral route (Figure 2C) with an $\mathrm{ED}_{50} \mathrm{ip} / \mathrm{ED}_{50}$ per os ratio $<6 \%$ in DMSO.

In comparison with these compounds, results obtained for another well-known anti-malarial drug, artesunate with the same four days experimental protocol were provided. Plasmodium vinckei-infected mice were treated via ip route at 1, 3, 10 and $30 \mathrm{mg} / \mathrm{kg} /$ day and per os route at 1, 4, 20 and $80 \mathrm{mg} / \mathrm{kg} /$ day. Artesunate exerts a very significant anti-malarial effect, with $\mathrm{ED}_{50}$ ip $<1 \mathrm{mg} / \mathrm{kg}$ and $\mathrm{ED}_{50}$ per os $=1.8 \mathrm{mg} / \mathrm{kg}$ (Figure 2D).

At day 5 after ip treatment, artesunate reduced parasitaemia by $70 \%$ at $1 \mathrm{mg} / \mathrm{kg}$. Higher doses were not able to clear parasitaemia and 3\% of the parasitaemia remained after treatment with $30 \mathrm{mg} / \mathrm{kg}$ ip. None of the tested doses allowed a complete cure and only 50\% survival was observed at $30 \mathrm{mg} / \mathrm{kg}$ ip. A similar profile was observed after oral administration, with an $E_{50}$ of $1.8 \mathrm{mg} / \mathrm{kg}$ and a decrease of parasitaemia by $93 \%$ at $4 \mathrm{mg} / \mathrm{kg}$.

\section{Pharmacokinetics}

A snapshot pharmacokinetic study was performed on hybrid 2, which was selected as an example in order to determine the pharmacokinetic properties of this class of anti-malarial drugs. Three mice were used for each experiment, each receiving $20 \mathrm{mg} / \mathrm{kg}$ orally or $2 \mathrm{mg} / \mathrm{kg}$ intravenously (IV). The plasma concentration profiles of the intact hybrid after oral and IV administration of hybrid $\mathbf{2}$ are displayed in Figure 3. The pharmacokinetic parameters for the oral and IV data of hybrid $\mathbf{2}$ are presented in Table 2.

A moderate pharmacokinetic profile was displayed by hybrid 2. After a dose of $20 \mathrm{mg} / \mathrm{kg}$ per os, a maximum oral concentration of $141 \pm 56.8 \mathrm{ng} / \mathrm{mL}$ was reached within $23.3 \pm 5.77 \mathrm{~min}$. The oral half-life was $3.91 \pm$ $0.68 \mathrm{~min}$, which was similar to the IV half-life (4.51 \pm $1.22 \mathrm{~min})$. The IV AUC was 32 times higher than the oral AUC (3463 \pm 895 ng.min/mL vs $112735 \pm$ 125766 ng.min/mL), whereas the IV dose was $2 \mathrm{mg} / \mathrm{kg}$. 

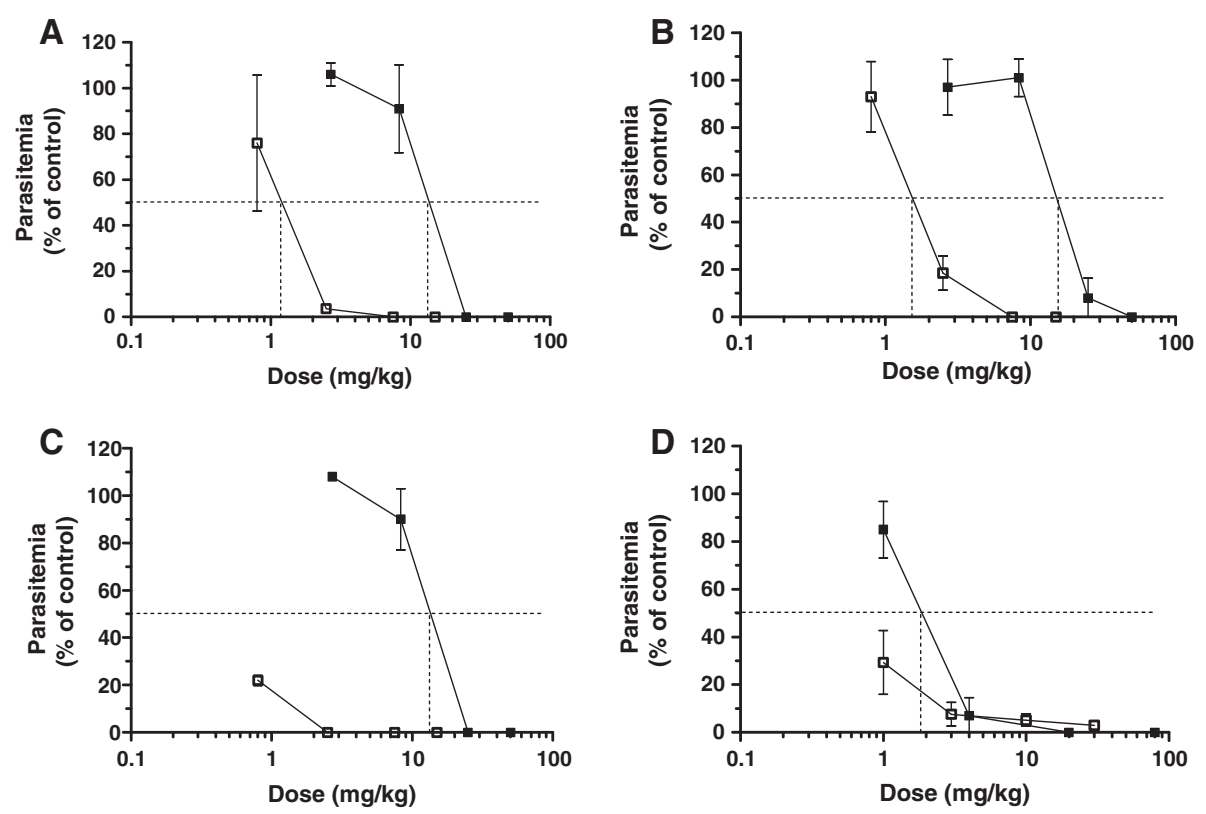

Figure $\mathbf{2}$ In vivo ED50 of hybrids $\mathbf{1}-\mathbf{3}$ and artesunate. The in vivo ED50 of hybrid $\mathbf{1}$ (A), hybrid $\mathbf{2}$ (B), hybrid $\mathbf{3}$ (C) and artesunate (D) was determined. Plasmodium vinckei-infected mice were treated once daily by ip (white squares) or po (black squares) injections for 4 consecutive days. Parasitaemia was monitored at day 5 and expressed as a percentage of the control. Results are the mean of at least 3 mice per dosage \pm SD.

The volume of distribution was $34 \pm 10.8 \mathrm{~L} / \mathrm{kg}$ after the oral dosage and $0.44 \pm 0.58 \mathrm{~L} / \mathrm{kg}$ for the IV dosage. Hybrid 2 presented a high oral clearance rate $(6.1 \pm$ $1.80 \mathrm{~L} / \mathrm{min} / \mathrm{kg})$ and low oral bioavailability $(0.31 \pm$ $0.08 \%)$. A linear pharmacokinetic profile was displayed by hybrid 2. For raw data of treatment with hybrid $\mathbf{1}$, see Additional files 1 and 2

\section{Discussion}

All three hybrids displayed potent low nanomolar in vitro anti-malarial activities, with $\mathrm{IC}_{50}$ values very closely related, ranging from $5.15-25.7 \mathrm{nM}$, whereas $2.09-5.11 \mathrm{nM}$ and $21.54-157.90 \mathrm{nM}$ were the ranges of DHA and CQ, respectively. The best in vitro activity against the $3 \mathrm{D} 7$ strain was displayed by hybrid $3\left(\mathrm{IC}_{50}=\right.$ $5.15 \mathrm{nM})$. It was clear from the data presented that this class of compounds displayed a very potent and rapid in vivo anti-malarial activity when optimum dosages were applied, resulting in recrudescence if otherwise applied.

Hybrid 1 demonstrated a potent anti-malarial activity via both intraperitoneal and oral routes. At $15 \mathrm{mg} / \mathrm{kg}$ ip and $50 \mathrm{mg} / \mathrm{kg}$ per os rapid and total parasitaemia clearance were induced. No visible sign of toxicity was observed up to $50 \mathrm{mg} / \mathrm{kg}$. No parasitaemia were observed on the smears form day 3 . Long term monitoring showed $100 \%$ survival on day 30 and no recrudescence was observed. Artemisinin hybrid $\mathbf{1}$ provided a total cure of malaria in vivo at these doses.

Hybrid 2 provided a complete clearance of parasitaemia and a total cure of malaria at $15 \mathrm{mg} / \mathrm{kg}$ by ip route and at $50 \mathrm{mg} / \mathrm{kg}$ by oral route. Compared to hybrid $\mathbf{1}$, hybrid 2 displayed similar efficiency against $P$. vinckei in vivo at the same doses allowing a total cure and similar $\mathrm{ED}_{50}$ values $(1.1$ and $1.4 \mathrm{mg} / \mathrm{kg}$ ip for hybrid
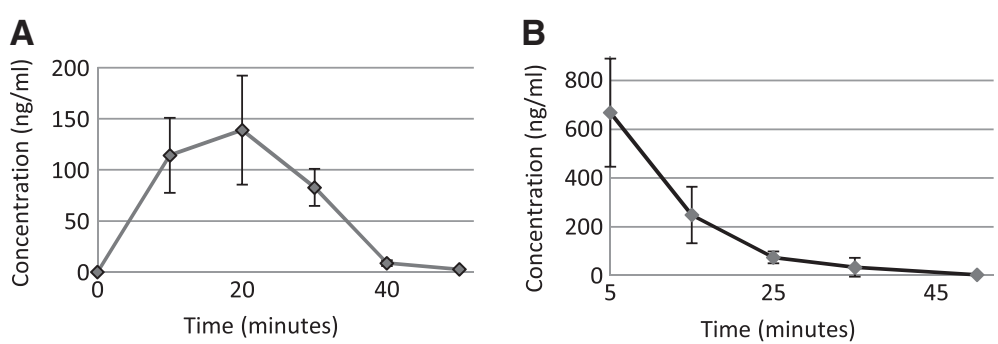

Figure $\mathbf{3}$ Pharmacokinetic plasma concentration profiles for hybrids $\mathbf{1}$ and 2. Plasma concentration profiles for hybrid $\mathbf{2}$ are shown on graph $\mathbf{A}$ after oral administration of $20 \mathrm{mg} / \mathrm{kg}$, whereas the $2 \mathrm{mg} / \mathrm{kg} \mathrm{IV}$ data are shown on graph $\mathbf{B}$. Results are the mean of at least $3 \mathrm{mice} \pm$ SD. 
Table 2 Pharmacokinetic parameters of hybrid 2 after oral and IV administration

\begin{tabular}{|c|c|c|}
\hline $\begin{array}{l}\text { Pharmacokinetic } \\
\text { parameter }\end{array}$ & $\begin{array}{c}\text { Hybrid } 2 \\
\text { Mean } \pm \text { SD (oral) }\end{array}$ & Mean \pm SD (IV) \\
\hline Cmax $[\mathrm{ng} / \mathrm{ml}]$ & $141 \pm 56.8$ & ND \\
\hline $\operatorname{Tmax}[\min ]$ & $23.3 \pm 5.8$ & ND \\
\hline Apparent Terminal t1⁄2 [min] & $3.9 \pm 0.7$ & $4.5 \pm 1.2$ \\
\hline$A \cup C_{0-\operatorname{lnf}}[\mathrm{ng} \cdot \mathrm{min} / \mathrm{ml}]$ & $3463 \pm 895$ & $112735 \pm 125766$ \\
\hline$V_{D} / F[L / k g]^{a}$ & $34 \pm 10.8$ & $0.4 \pm 0.6$ \\
\hline Plasma CL/F $[\mathrm{L} / \mathrm{min} / \mathrm{kg}]^{\mathrm{a}}$ & $6.1 \pm 1.8$ & $0.06 \pm 0.07$ \\
\hline$\% B A$ & $0.3 \pm 0.1$ & ND \\
\hline
\end{tabular}

${ }^{\mathrm{a}}$ For the oral experiment, apparent oral $\mathrm{CL}$ and $\mathrm{V}_{\mathrm{D}}$ were reported; $N D=$ not determined.

1 and hybrid 2, respectively and $12 \mathrm{mg} / \mathrm{kg}$ and $16 \mathrm{mg} / \mathrm{kg}$ per os for hybrid $\mathbf{1}$ and hybrid $\mathbf{2}$, respectively).

Although the four day treatment with hybrid $\mathbf{3}$ provided good anti-malarial efficacy against $P$. vinckei in vivo at $2.5 \mathrm{mg} / \mathrm{kg}$ ip and $25 \mathrm{mg} / \mathrm{kg}$ per os (doses where parasitaemia is less than $10 \%$ on day 5), survival rate was $66 \%$. Therefore, a complete clearance of parasitaemia and a total cure of malaria in vivo were not obtained by hybrid 3.

Artesunate, the reference drug, displayed $\mathrm{ED}_{50}$ ip and per os values of $<1 \mathrm{mg} / \mathrm{kg}$ and $1.8 \mathrm{mg} / \mathrm{kg}$, respectively. However, despite these low $\mathrm{ED}_{50}$ values, artesunate was only able to completely cure mice at doses about 40 times higher. Clearance of parasitaemia was only obtained at $30 \mathrm{mg} / \mathrm{kg}$ ip and $80 \mathrm{mg} / \mathrm{kg}$ per os, whereas complete clearance was obtained at $15 \mathrm{mg} / \mathrm{kg}$ ip and $50 \mathrm{mg} / \mathrm{kg}$ per os for hybrid $\mathbf{1}$ and 2.

The pharmacokinetic profile (mean \pm SD) of hybrid 2 was similar to that of DHA. Hybrid 2 reached a maximum concentration of $141 \pm 56.8 \mathrm{ng} / \mathrm{mL}$ within $23 \pm$ $5.77 \mathrm{~min}$ after a concentration of $20 \mathrm{mg} / \mathrm{kg}$ were administrated orally, whereas DHA reached a maximum concentration of $142.2 \pm 21.1 \mathrm{ng} / \mathrm{mL}$, in $48 \pm 6 \mathrm{~min}$ after a dose of $10 \mathrm{mg} / \mathrm{kg}$ [20]. However, according to the recorded data DHA displayed a much longer half-life ip than hybrid 2 (25 $\mathrm{min} v s 3.9 \mathrm{~min}$ ) [21]. Subsequently DHA also displayed a higher AUC than hybrid 2 (8748 \pm 2016 ng.min $/ \mathrm{mL}$ vs $3463 \pm 895$ ng.min/mL) [20]. The oral volume of distribution of DHA was higher than that of hybrid $2(353.5 \pm 194.9 \mathrm{~L} / \mathrm{kg}$ vs $34 \pm 10.8 \mathrm{~L} / \mathrm{kg})$, whereas the clearance rate for hybrid 2 was 5 times that of DHA (6.1 L/min $/ \mathrm{kg}$ vs $1.19 \mathrm{~L} / \mathrm{min} / \mathrm{kg})$ [20]. Hybrid 2 resulted in a significantly lower oral bioavailability, $0.31 \%$, compared to $19-35 \%$, which has been reported for artemisinin derivatives [22].

The high values for oral artemisinin clearance either indicated moderate absorption or high first-pass extraction, which also explain the time dependency of DHA [4] and hybrid 2. Moderate bioavailability displayed by hybrid 2 could be explained by rapid metabolism. However, metabolites - not identified by the LC/MS/MS assay - are expected to be very active due to their potent in vivo anti-malarial activity.

\section{Conclusions}

Hybrids 1 and 2 were able to completely cure mice at $15 \mathrm{mg} / \mathrm{kg}$ via the intraperitoneal route and at $50 \mathrm{mg} / \mathrm{kg}$ for oral route, whereas artesunate is only able to provide a complete cure at $30 \mathrm{mg} / \mathrm{kg}$ ip and $80 \mathrm{mg} / \mathrm{kg}$ per os. The artemisinin-quinoline hybrids displayed significant anti-malarial activity by ip route with $\mathrm{ED}_{50}$ values of 1.1, 1.4 and $<0.8 \mathrm{mg} / \mathrm{kg}$ for hybrids $\mathbf{1}, \mathbf{2}-\mathbf{3}$, respectively.

Despite a short half-life and moderate oral bioavailability of the parent drug (as seen for hybrid 2), this class of compounds was able to cure malaria in mice at very low dosages, implying that the compounds are metabolized to active metabolites. The next step will be to conduct a comprehensive pharmacokinetic study, including metabolite identification.

In this study the optimum linker length for in vivo anti-malarial activity was found to be a diaminoalkyl chain consisting of two carbon atoms either methylated or unmethylated as in hybrids $\mathbf{1}$ and $\mathbf{2}$. By introducing another carbon atom in the linker chain, as in hybrid 3, the survival rate was reduced from $100 \%$ to $66 \%$ at the same dosages.

\section{Additional files}

\section{Additional file 1: Raw data of treatment with hybrid 1 by ip route. \\ Parasitaemia of $P$. vinckei infected mice treated during four days \\ $\left(D_{1}\right.$ to $\left.D_{4}\right)$ with hybrid 1 by intraperitoneal route at $0.8,2.5,7.5$ and \\ $15 \mathrm{mg} / \mathrm{kg}$. \\ Additional file 2: Raw data of treatment with hybrid 1 by po route. \\ Parasitaemia of $P$. vinckei infected mice treated during four days \\ $\left(D_{1}\right.$ to $\left.D_{4}\right)$ with hybrid 1 by oral route at $2.7,8.3,25$ and $50 \mathrm{mg} / \mathrm{kg}$.}

\section{Abbreviations}

ACT: Artemisinin combination therapy; Ip: Intraperitoneal route; per os: Oral route; IV: Intravenous; Rl: Resistance index; SI: Selectivity index;

DHA: Dihydroartemisinin; CQ: Chloroquine.

\section{Competing interests}

The authors declare that they have no competing interests.

\section{Authors' contributions}

$M C L$ synthesized compounds, conceived and designed the experiments and wrote the manuscript. DDN was involved in revising the manuscript, JN statistically analysed pharmacokinetic data and revised the manuscript, CTVB and SW performed anti-malarial tests and analysed the data, LW was responsible for the coordination of the pharmacokinetic analysis and revised the manuscript and HV conceived anti-malarial testing and wrote the manuscript. All authors read and approved the final manuscript.

\section{Acknowledgements}

$M C L$ and DDN would like to thank the National Research Fund (NRF) and the North-West University for the financial support of this study. The authors would like to acknowledge Alicia Evans for performing the pharmacokinetic analysis and Trevor Finch for conducting the pharmacokinetic animal work. 
LW would like to thank the Medical Research Council (MRC) self-initiated funds for making the pharmacokinetic work possible.

\section{Author details}

'Pharmaceutical Chemistry, North-West University, Potchefstroom 2531, South Africa. ${ }^{2}$ Centre National de la Recherche Scientifique, Université Montpellier 2, 34095, Montpellier Cedex 05, France. ${ }^{3}$ Division of Clinical Pharmacology, Department of Medicine, University of Cape Town, Cape Town 7925, South Africa.

Received: 22 August 2012 Accepted: 12 February 2013

Published: 21 February 2013

\section{References}

1. Dondorp AM, Nosten F, Yi P, Das D, Phyo AP, Tarning J, Lwin KM, Ariey F, Hanpithakpong W, Lee SJ, Ringwald P, Silamut K, Imwong M, Chotivanich K, Lim P, Herdman T, An SS: Artemisinin resistance in Plasmodium falciparum malaria. N Engl J Med 2009, 361:455-467.

2. Dondorp AM, Yeung S, White L, Nguon C, Day NPJ, Socheat D, von Seidlein $L$ : Artemisinin resistance: current status and scenarios for containment. Nat Rev Micro 2010, 8:272-280.

3. Phyo AP, Nkhoma S, Stepniewska K, Ashley EA, Nair S, McGready R, Ler Moo C, Al-Saai S, Dondorp AM, Lwin KM, Singhasivanon P, Day NP, White NJ, Anderson TJ, Nosten F: Emergence of artemisinin-resistant malaria on the Western border of Thailand: a longitudinal study. Lancet 2012, 379:1960-1966.

4. Ashton M, Hai TN, Sy ND, Huong DX, Van Huong N, Niêu NT, Công LD: Artemisinin pharmacokinetics is time-dependent during repeated oral administration in healthy male adults. Drug Metab Dispos 1998, 26:25-27.

5. Liu T, Du F, Wan Y, Zhu F, Xing J: Rapid identification of phase I and II metabolites of artemisinin antimalarials using LTQ-Orbitrap hybrid mass spectrometer in combination with online hydrogen/deuterium exchange technique. J Mass Spec 2011, 46:725-733.

6. Asimus S, Elsherbiny D, Hai TN, Jansson B, Huong NV, Petzold MG, Simonsson USH, Ashton M: Artemisinin antimalarials moderately affect cytochrome P450 enzyme activity in healthy subjects. Fundam Clin Pharmacol 2007, 21:307-316.

7. Meunier B: Hybrid molecules with a dual mode of action: dream or reality? Acc Chem Res 2008, 41:69-77.

8. Grelepois F, Grellier P, Bonnet-Delpon D, Begue J: Design, synthesis and antimalarial activity of trifluoromethylartemisinin-mefloquine dual molecules. Chembiochem 2005, 6:648-652.

9. Singh C, Malik H, Puri SK: Synthesis and antimalarial activity of a new series of trioxaquines. Bioorg Med Chem 2004, 12:1177-1182.

10. Benoit-Vical F, Lelievre J, Berry A, Deymier C, Dechy-Cabaret O, Cazelles J, Loup C, Robert A, Magnaval JF, Meunier B: Trioxaquines are new antimalarial agents active on all erythrocytic forms, including gametocytes. Antimicrob Agents Chemother 2007, 51:1463-1472.

11. Cosledan F, Fraisse L, Pellet A, Guillou F, Mordmuller B, Kremsner PG, Moreno A, Mazier D, Maffrand JP, Meunier B: Selection of a trioxaquine as an antimalarial drug candidate. Proc Natl Acad Sci USA 2008, 105:17579-17584.

12. Dechy-Cabaret O, Benoit-Vical F, Loup C, Robert A, Gornitzka H, Bonhoure A, Vial H, Magnaval J, Séguéla J, Meunier B: Synthesis and antimalarial activity of trioxaquine derivatives. Chem Eur J 2004, 10:1625-1636.

13. Walsh JJ, Coughlan D, Heneghan N, Gaynor C, Bell A: A novel artemisininquinine hybrid with potent antimalarial activity. Bioorg Med Chem Lett 2007, 17:3599-3602.

14. Walsh JJ, Bell A: Hybrid drugs for malaria. Curr Pharm Des 2009, 15:2970-2985.

15. Lombard MC, N'Da DD, Breytenbach JC, Smith PJ, Lategan CA: Synthesis, in vitro antimalarial and cytotoxicity of artemisinin-aminoquinoline hybrids. Bioorg Med Chem Lett 2011, 21:1683-1686.

16. Lombard MC, Fernandes MA, Breytenbach JC, N'Da DD: 2-(10ßdihydroartemisinoxy)ethylbromide. Acta Crys E 2010, E66:2182-2183.

17. Trager W, Jensen JB: Human malaria parasite in continuous culture. Science 1976, 193:673-675.

18. Desjardins RE, Canfield CJ, Haynes JD, Chulay JD: Quantitative assessment of antimalarial activity in vitro by a semiautomated microdilution technique. Antimicrob Agents Chemother 1979, 16:710-718.
19. Barkan D, Ginsburg H, Golenser J: Optimisation of flow cytometric measurement of parasitaemia in Plasmodium-infected mice. Int I Parasitol 2000, 30:649-653.

20. Xing J, Yan H, Wang R, Zhang L, Zhang S: Liquid chromatography-tandem mass spectrometry assay for the quantitation of $\beta$-dihydroartemisinin in rat plasma. J Chromatogr B 2007, 852:202-207.

21. Batty KT, Gibbons PL, Davis TME, llett KF: Pharmacokinetics of dihydroartemisinin in a murine malaria model. Am J Trop Med Hyg 2008, 78:641-642.

22. Navaratnam V, Mansor SM, Sit N, Grace J, Li Q, Olliaro P: Pharmacokinetics of artemisinin-type compounds. Clin Pharmacokinet 2000, 39:255-270.

doi:10.1186/1475-2875-12-71

Cite this article as: Lombard et al: Potent in vivo anti-malarial activity and representative snapshot pharmacokinetic evaluation of artemisininquinoline hybrids. Malaria Journal 2013 12:71.

\section{Submit your next manuscript to BioMed Central and take full advantage of:}

- Convenient online submission

- Thorough peer review

- No space constraints or color figure charges

- Immediate publication on acceptance

- Inclusion in PubMed, CAS, Scopus and Google Scholar

- Research which is freely available for redistribution

Submit your manuscript at www.biomedcentral.com/submit
C Biomed Central 